\title{
Learning strategies applied by the students in writing English text
}

\author{
Dwiana Binti Yulianti \\ chayrana80@gmail.com \\ Muhammadiyah University of Ponorogo \\ Jl. Budi Utomo No. 10, Ponorogo, JawaTimur, Indonesia
}

Received: May 13, 2017;

Accepted: February 2, 2018;

Published: March 2, 2018

\begin{abstract}
This study is aimed at verifying the finding of a study on what learning strategies applied by the students in writing text and the impact of learning strategies toward the students' writing score. This is a qualitative descriptive study, and it is conducted at Communication Science Department of the Muhammadiyah University of Ponorogo. The instruments used to collect the data were observation, documentations, and questionnaire. After analyzing the data, it is found that the learning strategies used by the students in writing English text are metacognitive strategies, compensation strategies, cognitive strategies, affective strategies, memory strategies, and social strategies. The students use learning strategies in moderate level which means they sometimes use these learning strategies. Moreover, learning strategies influence the students' writing score; the students who get good score use metacognitive strategies and the students who get fair score use affective strategies.
\end{abstract}

Keywords: learning strategy, writing, writing English text

How to cite this paper: Yulianti, D. B. (2018). Learning strategies applied by the students in writing English text. Journal on English as a Foreign Language, 8(1), 1938 (doi: 10.23971 ßefl.v8i1.583)

DOI: http://dx.doi.org/10.23971 ßefl.v8i1.583

Writing is one of the English skills. Writing covers the great range of styles a student will perform in his daily lives. It may include filling forms, making lists, writing letters, note-taking, or academic writing. Writing develops students' critical thinking to express what they think and convey their idea in

Journal on English as a Foreign Language, 8(1), 19-38

Copyright @ 2018 by JEFL, p-ISSN 2088-1657; e-ISSN 2502-6615 
arrangement of sentence. Therefore, the students require a lot of attempts to produce complete meaning. Most of the students think that writing is the difficult skill for them.

The difficulties are caused some factors such as lack of vocabulary, lack of grammar understanding, lack of motivation, or even lack of confidence. Moreover, the atmosphere in the class also influences the students to write. When the atmosphere of the class is not conducive, it will make the students bored. Consequently, the students will not encourage in expressing their idea. In addition, Mukminatien as cited in Miftah (2015b, p. 9) points out that the difficulties are not merely caused by the students themselves but they can also be caused by the unvaried and uninteresting techniques of the teachers in teaching writing. It will make boredom for the students and have less motivation in learning writing.

Furthermore, Abu as cited in Alfaki (2015) states that writing is a difficult skill for native speakers and non-native speakers alike because writers must balance multiple issues such as content, organization, purpose, audience, vocabulary, punctuation, spelling and mechanics. Furthermore, Alfaki (2015) states that there are some problems faced by students in writing, namely grammatical problems, mechanical problems, sentence structure problems and problems of diction. These problems are caused by lack learners' motivation, inadequate time, lack of practice, and teachers' feedback.

Having good ability in writing is beneficial for the students. Firstly, writing is a good way to help develop their ability of using vocabulary and grammar, increasing the ability of using language. Secondly, writing is an essential tool to support other skills. If a student has good writing ability, they can speak and read the text more effectively. Thirdly, writing is a way to approach modern information technology as well as the human knowledge. Otherwise, it is necessary to master writing skill because it can help students have a well prepared when finding a job or attend English courses (Alfaki, 2015). For those benefits, writing is really very important to every student.

Dealing with the importance of the writing for the students, teacher should encourage the students to create their habit in writing. Harmer as cited in Miftah (2015a, p. 63) suggests that it is encouraged to build the students" writing habit. Many students either think or say that they cannot, or do not want to write. This may be because of their lack of confidence. They think that writing is boring. Therefore, the teacher needs to engage them, from early levels, with easy and enjoyable activities as their habit, so that writing activities not only become a normal part of the classroom but also present opportunities for students to achieve almost instant success. 
In the term of the engagement of the students in language learning, teachers need to know about the learning strategies used by the students in their learning. Moreover, learning outcomes are really influenced by the learning process and the learning process is influenced by the characteristics of the learners and also the learning situation (Arulselvi, 2006). In Communication department of Muhammadiyah University of Ponorogo, English subject is as general course. It means that English has small part in teaching learning process. The students have limitation to study and practice about English and they even interact with English rarely. Besides, because of non-English department, the students of Communication department have limited knowledge about English so that they have difficulties in mastering English. In some cases, English is important for them as additional knowledge and supporting ability. Thus, they are not fully aware of their English learning and how they can obtain the optimal learning result by ensuring their strategies (Gestanti, 2017). In addition, the teachers have to know the strategy used by their students to control their learning since we know that English as the second language for the students and of course English words have different pronunciation with the written words (Rini, 2016). Therefore, it is expected for the teacher to know about what kind of learning strategies used by the students in writing English text and how the impact of these strategies in the students' writing score to be able to guide the students in learning English.

Dealing with teaching writing, Biare as cited in Reszy (2013) mentions that in teaching writing the result have to be achieved at the end of teaching and the learning process have to be started. That are the product must the goal of learning and the process of writing must take the students learn how to write in a right way. Then, strategy and technique are a matter of teacher creativity to conduct the class. So teaching writing is how the teacher facilitates, motivate and encourage the students to express their ideas in writing form. Brainstorming is one of teaching technique in writing. Brainstorming helps the students in generating ideas. Moreover, brainstorming is a way to discover ideas about the topic and it will help the students to focus more clearly on a particular idea which best support the topic. Then, brainwriting is one of the alternatives of brainstorming that can be offered in the class. Brainwriting is as a worthy, and sometimes preferred, alternative to brainstorming. The term "brainwriting" often brings forth smiles and quiet laughter because it is a strange word. Brainwriting is simple but enjoyable technique in teaching writing (Virdyna, 2016).

Regarding to the writing, academic writing ability is particularly recognized as one of the most crucial aspects of language ability for successful academic achievement. Therefore, in the process of writing the students may 
use language learning strategies so that they can get better result in completing their writing tasks (Mutiatun, 2017).

Broadly speaking about learning strategies, Rigney and Rubin as cited in Lee (2010), define language learning strategies as behaviors, steps, or techniques that language learners apply to facilitate language learning. It means that the students can decide certain strategies or think ways while they are learning English to enhance their own learning. Thus, Weinstein and Mayer as cited in Ching-Yi (2007) proposed learning strategies as "behaviors and thoughts that a learner engages in during learning and that are intended to influence the learner's encoding process". Next, Bialystok as cited in Ching-Yi (2007) defined language learning strategies as "optional means for exploiting available information to improve competence in a second language. Chamot as cited in Ching-Yi (2007) gave a definition of language learning strategies as "techniques, approaches or deliberate actions that students take in order to facilitate the learning and recall of both linguistic and content area information". She proposed that some language learning strategies are observable, but some may not be observable. Rigney and Rubin as cited in Lee (2010) define language learning strategies as behaviors, steps, or techniques that language learners apply to facilitate language learning.

Moreover, Stern as cited in Himasnoglu (2000) states that the concept of learning strategy is dependent on the assumption that learners consciously engage in activities to achieve certain goals and learning strategies can be regarded as broadly conceived intentional directions and learning techniques. Generally, language learning strategies are used by all of the language learners. They use it either consciously or unconsciously in getting new information and carrying out tasks in their classroom. Language classroom is just like a problemsolving situation in which language learners are expected to face new knowledge and difficult assignments given by their teachers, learners' attempts to discover the quickest or easiest method to complete it so that they use language learning strategies (Himasnoglu, 2000).

Oxford as cited in Alfian (2016) states that language learning strategy in general plays a very essential role in the language learning process. It represents one of the most critical components in language learning. Language learning strategy is especially important for language learning because they are tools for active, self-directed movement, which is essential for developing communicative competence. Moreover, language learning strategy leads the students to be active in the class so that the class will be student-centered learning environment. Consequently, students will be independent students so that they can handle their problems well. 
Learners use various operations in order to make sense in their learning. Then, in accomplishing their tasks, the students have some resources that they use to make perfect their tasks (Hardan, 2013). Learning strategies are operationalized as the ways that language learners use to improve their language knowledge and performance (Tran-Hoang-Thu, 2009). Learning strategies are not only aid language learning but also the learning of other subject such as Maths, Biology, etc. Learning strategies are teachable and the format of instruction has to be direct and integrated (Araúz, 2009). In this case, when learners start to learn something, they have the ability to respond to the particular learning situation and manage their learning in appropriate way. Hence, learning strategy is like footballer who use tactics in order to win game when they are in the stadium. Learners use learning strategies in order to make their learning successfully. Therefore, learning strategies have significant part in language process. Learning strategies is a term that refers to technique and tactic that learners use in practicing language activities (Hardan, 2013).

Cyr as cited in Ungureanu (2012) states that the students need five steps in practicing learning strategies. The steps are: decide strategies they use, present and explain the strategies and the way they are use, regulate the strategy, practice the strategy and establish the relation between strategy and motivation. In helping students to reach a better autonomy, and taking into account their needs, there are five steps that can be done, namely: planning a training session on learning strategies in order to make students aware which are their strengths and weaknesses regarding their personal learning strategies. Then, focusing on choosing activities aimed at showing the students the mechanics of each strategy. Next, asking students practice the necessary strategies so that they reach autonomy in learning. Fourthly, related to the fact that students should become aware that their failure is due to the use of an inappropriate learning strategy rather than to an insufficiently developed skill. The last, giving the feedback the teacher requires following completeness of the previous steps. Furthermore, Cyr as cited in Ungureanu (2012) argues that there are three stages to be followed by teachers in order to train students to use learning strategies, namely observing students' learning strategies, involving the issue of strategies in teaching and teachers' and students' commonly assessing the strategies used.

Learners can select and apply the learning strategies based on instructional variable such as differences, types of domains, teaching methods, amount of time, learning technologies, kinds of feedback, required level of mastery, ways of measurement etc. It is caused by a wide variety of learning strategies in learning process (Simsek, 2010). Speaking about choosing learning strategies used by the students, there are several factors influencing students in 
using language learning strategies. Some researchers according to Lee (2010) mention that age, sex, attitude, motivation, aptitude, learning stage, task requirements, teacher expectation, learning styles, individual differences, motivation, cultural differences, beliefs about language learning, and language proficiency as several factors that influence students in applying learning strategies. Furthermore, Liang as cited in Gestanti (2017) mentions four factor influencing students in choosing learning strategies. Those are learner factor (learners' thought, language learning styles, ages, gender, and students' motivation); situational factor (learning setting and task types); academic factor (academic major); and cultural background (nationality and ethnicity).

Learning strategies are much beneficial in learning process. Learning strategies facilitate the students to reveal their own way of learning, recognize their identity as "learners" and be aware of their difficulties in learning. In addition, learning strategies enable the students to communicate with others so that they can stimulate their previous knowledge in holding the materials and correlating the new information. Learning strategies not only lead the students to accomplish the examination well but also is more profitable in the future because it is lasting and functional (Arulselvi, 2006).

Learning strategies that used by the language learners in the process of language learning have been recognized and classified by some researchers. By knowing the classification of the learning strategies, it will help both the teachers and the language learners in understanding and applying it in their language learning. Basically, these professional experts have same classification (Ching-Yi., 2007; Hardan, 2013; Himasnoglu, 2000; Liu, 2010; Oxford, 2003; Tran-Hoang-Thu, 2009; and Zare, 2012). Following are the classification of learning strategies proposed by them.

Rubin as cited in Zare (2012) classified learning strategies according to processes which provide either directly or indirectly to language learning. Therefore, Rubin as cited in Zare (2012) made distinction between strategies contributing directly to learning and those contributing indirectly to learning. Direct strategies include metacognitive and cognitive strategies and indirect strategies include communicative and social strategies. According to Rubin, there are three types of strategies used by learners that contribute either directly or indirectly to language learning. They are learning strategies, communication strategies, and social strategies.

The first type is learning strategies. These learning strategies contribute directly to the development of the language system created by the language learner. These are divided into two main majors that are Cognitive Learning Strategies and Metacognitive Learning Strategies. Cognitive strategies refer to the steps or processes used in learning or problem-solving tasks that require 
direct analysis, transformation, or synthesis of learning materials. These strategies are divided into: clarifications refer to the learners in clarifying the understanding of the new language; guessing refers to strategies used previously to obtain the knowledge; deductive reasoning is problem-solving strategies; practice focuses on accuracy of usage; memorization focuses on the storage and retrieval of language; and monitoring refers that the learner notices error. While, Metacognitive strategies are used to supervise, control or selfdirect language learning. They involve a variety of processes as planning, prioritizing, setting goals, and self-management.

The second type is Communication strategies. Communication strategies are less directly related to language learning because they focus on the process of participating in a conversation and getting meaning across or clarifying what the speaker intended. These strategies are used by speakers when they are confronted with misunderstanding by a co-speaker.

The third type is Social Strategies. Social strategies are activities in which learners are exposed to the opportunities that can be a great help to practice their knowledge. Even though these strategies provide exposure to the target language, they contribute indirectly to the obtaining, storing, retrieving, and using of language.

O'Malley and Chamot's as cited in Zare (2012) classification become known because of interviews with experts and novices and theoretical analyses of reading comprehension and problem solving. In this classification, language learning strategies are distinguished into three main categories; they are cognitive, meta-cognitive and social/affective strategies.

The first category is Cognitive Strategies. Brown as cited in Zare (2012) states that Cognitive Strategies are not only more limited to specific learning tasks but they also involve more direct manipulation of the learning material itself. Among the most important cognitive strategies are repetition, elaboration, contextualization, auditory representation, transfer, and inference are among the most important cognitive strategies.

Then, the second category is Meta-cognitive strategies. O'Maley et al. as cited in Zare (2012) state that metacognitive is an expression to indicate an executive function, strategies which involve planning for learning, thinking about the learning process as it is taking place, observing of one's production or comprehension, correcting your own mistakes, and evaluating learning after an activity is completed. Based on O'Malley's classification, advance organizers, directed attention, selective attention, self-management, functional planning, self-monitoring, delayed production, and self-evaluation are included among the major metacognitive strategies. 
The last category is Social/affective strategy. Social/affective strategies can be stated that they involve interaction with another person. They are generally considered to be applicable to various tasks. Questioning for clarification, cooperation with others to solve a problem, rephrasing, and selftalk are some examples of socio-affective strategies.

Oxford divided language learning strategies into two major classes; direct and indirect strategies. Then, it is subdivided into six classes. The first class is direct strategies. Direct strategies are those behaviors that directly involve the use of the target language, which directly facilitates language learning. Thus, direct strategies are divided into three subcategories; Memory, Cognitive and Compensation Strategies.

Memory strategies involve the mental processes for storing new information in the memory and for retrieving them when needed. These strategies consist of four sets that include: creating mental linkages, applying images and sounds, reviewing well, and employing action.

Cognitive strategies involve conscious ways of handling the target language and fall into four sets which include: practicing, receiving and sending messages, analyzing and reasoning, and creating structure for input and output.

Compensation strategies help learners to use the target language for either comprehension or production in spite of the limitations in knowledge. They aim to make up for a limited repertoire of grammar and, particularly vocabulary. When learners are confronted with unknown expressions, they make use of guessing strategies, which are also known as inference.

The second class is indirect strategies. Oxford as cited in Zare (2012) stated that indirect strategies provide indirect support for language learning by employing different strategies such as focusing, arranging, evaluating, seeking opportunities, and lowering anxiety. Indirect strategies are divided into three subcategories as well: Metacognitive, Affective, and Social Strategies.

Metacognitive strategies enable learners to control their own cognition. They are strategies which entail overviewing and linking with material already known, paying attention, delaying speech production, organizing, setting goals and objectives, planning for a language task, looking for practice opportunities, self-monitoring and self-evaluating.

Affective strategies assist students to manage their emotions, motivation, and attitudes associated with learning. They can be achieved through lowering anxiety, encouraging oneself, and taking emotional temperature.

Social strategies involve language. Since language is a form of social behavior, it involves communication between and among people. They enable language learners to learn with others by making use of strategies such as 
asking questions, cooperating with others, and empathizing with others. Yet, their appropriate use is extremely important since they determine the nature of communication in a learning context.

Among the existing learning strategies above, Oxford's classification provides the most extensive classification of language learning strategy. Oxford's classification overlaps others with a great extent. It is more comprehensive and more detail. Besides, it has systematic in linking individual and group strategies with each of the four language skills. Furthermore, it tries to complete the existing classification in order to ease the students in recognizing the strategies they use. Later, Oxford (2003) develops a set questionnaire along with its scoring system that is be used as the main instrument in identifying the students' learning strategies called the Strategy Inventory for Language Learning (SILL) to collect data regarding languagelearning strategies.

Similarly, Purpura as cited in Alfian (2016) states that Oxford's model has been developed into questionnaire which is called SILL, or Strategy Inventory for Language Learning, and has been widely used all over the world to conduct language learning strategy research. SILL is the preferred model because it provides a clear hierarchical organization. It also covers a lot of strategy. Moreover, the categories are comprehensive, appealing, and unique.

Since this research concerns on investigating students' learning strategies in writing, then, it will be described the related strategies for writing. The strategies are: 1) Direct Strategies consist of memory strategies, cognitive strategies, and compensation strategies. Memory strategies that would be useful for writing as follow: creating mental linkages: (1) placing new words into a context; reviewing well: (1) structured reviewing; and Employing action: (1) using mechanic technique

Then, cognitive strategies involved: Practicing consists of (1) repeating, (2) formally practicing with sounds and writing systems, (3) recognizing and using formulas and patterns, (4) recombining, (5) practicing naturalistically; Receiving and sending message that consist of (1) using resources for receiving and sending messages; and analyzing and reasoning that consist of (1) reasoning deductively, (2) translating, and (3) transferring d) Creating structure for input and output: (1) taking notes, (2) summarizing, and (3) highlighting.

The last strategy of direct strategies is compensation strategies. Compensation strategies involve overcoming limitation that consists of (1) selecting the topic, (2) adjusting or approximating the message, (3) coining words, and (4) using a circumlocution or synonym.

The second class is Indirect Strategies that consist of metacognitive Strategies, affective strategies, and social strategies. Metacognitive strategies 
involved: centering your learning that consist of (1) overviewing and linking with already known material, (2) paying attention; Arranging and planning your learning that consist of (1) finding out language learning, (2) organizing, (3) setting goals and objectives, (4) identifying the purpose of language task, (5) planning for a language task, (6) seeking practice opportunities; and evaluating your learning that consist of (1) self-evaluating, (2) self-monitoring

Next, affective Strategies involve: lowering your anxiety that consist of (1) using progressive relaxation, deep breathing or meditation, (2) using music, (3) using laughter; encouraging yourself that consist of 1) making positive statement, (2) taking risks wisely, (3) rewarding yourself; and taking your emotional temperature that consist of (1) listening to your body, (2) using checklist, (3) writing a language learning diary, (4) discussing your feeling with someone else.

The last, Social Strategies that involve: Asking questions in the form of (1) asking for correction; cooperating with others in the form of (1) cooperating with peers, (2) cooperating with proficient users of the new language; and empathizing with others in the form of (1) developing cultural understanding, (2) becoming aware of others' thoughts and feelings.

Based on the background of the study, this study is aimed at verifying the finding of a qualitative study on what learning strategies applied by the students in writing text and the impact of learning strategies toward the students' writing score. Finally, being familiar with learning strategies is beneficial for both teacher and student. Teacher is able to design the materials well then the students are able to take the learning strategies for their learning. In learning writing, the students are expected to be able to define the kind of learning strategies that suit for them so that they can improve and develop their writing skill.

\section{METHOD}

This research is included in qualitative research. The data collected are in the form of words or pictures rather than numbers. The study was conducted at the Muhammadiyah University of Ponorogo. The subjects of this research are the second-semester students of Communication Science Department and purposive sampling is used as the sampling technique.

There are three techniques which are used to collect data for the purpose of this research. The techniques are questionnaire, observation, and documentations. Questionnaire in the form of SILL questionnaire that consists of some items of learning strategies were delivered to the students to know the learning strategies used by the students. Then, observation was done to observe 
the learning process. In addition, to complete collecting the data, documentations in the form of the students' writing score was used.

Then, in analyzing the data, the researcher used Flow Model proposed by (Schutt, 2014). The Flow model of data analysis is divided into four parts: data collection, data reduction, data display, and drawing conclusion and verification. In analyzing the study, the questionnaires filled by the students were categorized based on Oxford's classification. Then, the result was examined with the students' writing score. Next, verifying was done in the last step.

\section{FINDINGS}

\section{Learning Strategies Applied by the Students in Writing English Text}

Based on the data gained using the questionnaire, Strategy Inventory of Language Learning or well-known as SILL proposed by Oxford (2003) consisting of 28 items which cover the six of learning strategies: memory, cognitive, compensation, metacognitive, affective, and social strategies, the findings are shown in Table 1.

Table 1. Average Score Scale of SILL

\begin{tabular}{llc}
\hline \multirow{2}{*}{ Frequency Level } & \multicolumn{1}{c}{ Description } & Range of Score \\
\hline High & Always or almost always used & 4.5 to 5.0 \\
\cline { 2 - 3 } & Usually used & 3.5 to 4.4 \\
\hline Moderate & Sometimes used & 2.5 to 3.4 \\
\hline \multirow{2}{*}{ Low } & Generally not used & 1.5 to 2.4 \\
\cline { 2 - 3 } & Never or almost never used & 1.0 to 1.4
\end{tabular}

Source: Questionnaire and Document Analysis of SILL (Oxford, 2003)

Table 1 shows how often the students use the learning strategies. High frequency level means that students almost or at least usually use the learning strategies in which the scores are ranging from 3.5 to 5.0.Moderate frequency level means that the students only sometimes use the learning strategies in which the scores are ranging from 2.5 to 3.4. Lastly, low frequency level means that the students rarely or even never use the learning strategies in which the scores are ranging from 1.0 to 2.4. Moreover, the result of this average score on each strategies was also used to determine what strategies mostly used or least used by the students in writing. In addition, the findings of the average score for every learning strategy are shown in Table 2. 
Table 2.The Average Score for Every Strategy

\begin{tabular}{llc}
\hline \multicolumn{1}{c}{$\begin{array}{c}\text { Kinds of } \\
\text { strategies }\end{array}$} & \multicolumn{1}{c}{ Strategies used } & Average score of strategies use \\
\hline Indirect & Metacognitive & 3.2 \\
\hline Direct & Compensation & 3.0 \\
\hline Direct & Cognitive & 2.9 \\
\hline Indirect & Affective & 2.9 \\
\hline Direct & Memory & 2.8 \\
\hline Indirect & Social & 1.8 \\
\hline
\end{tabular}

Source: Questionnaire and Document Analysis of SILL (Oxford, 2003)

The table 2 explains about the learning strategies most used by the students in writing class is metacognitive strategies in which the average score is 3.2. Then, the second level is compensation strategies in which the average score is 3.0. Next, cognitive and affective strategies in which average score 2.9. The fourth is memory strategies in which the average score is 2.8 . The last is social strategies in which the average score is 1.8 . From the score above, it is obtained that the mean score of the use of learning strategies is 2.7 and this score is involved to moderate level. It means that the students sometimes use learning strategies in their learning.

The followings are the detail explanations of learning strategies applied by the students in the writing class.

\section{Metacognitive Strategies}

It is one of indirect strategies. In these strategies, the students try to arrange their activities schedule themselves, based on their ability. These strategies involve planning, prediction, monitoring, revising, checking, and evaluating. The strategies related to students' motivation in doing activity so that they get result based $n$ their expectation.

The components of metacognitive strategies used in writing are: 1) centering your learning, in the form of overviewing and linking with already known material and paying attention; 2) arranging and planning your learning, in the form of finding out language learning, organizing, setting goals and objectives, identifying the purpose of the language task, planning for language task, seeking practice opportunities; 3) evaluating your learning includes selfmonitoring and self-evaluating. Based on the result of SILL, component of metacognitive strategies used by the students in writing are: 1) arranging and 
planning your learning, includes finding out language learning, organizing, setting goals and objectives, planning for a language task, seeking practice opportunities, and 2) evaluating your leaning, in the form of self-monitoring and self-evaluating.

\section{Compensation Strategies}

These strategies enable the students to guess the words they don't know the meaning. The students may guess the words based on the language context. The component of compensation strategies used in writing are providing limitations in writing in the form of selecting the topic, adjusting or approximating the message, coining words, and using a circumlocution or synonym. While, the components used by the students are: providing limitations in writing in the form of coining words, selecting the topic, and using a circumlocution or synonym.

\section{Cognitive and Affective Strategies}

Cognitive strategies relate to the students' learning process, thinking process, solving problems, remembering and thinking. While, affective strategies relate to students' emotion and feeling. Affective aspects concern about students' interest and behavior.

Component of cognitive strategies used in writing are 1) practicing, in the form of repeating, formally practicing with patterns and writing system, recognizing and using formulas and patterns, recombining, practicing naturalistically; 2) receiving and sending message, in the form of using resources for receiving and sending message; 3 ) analyzing and reasoning, in the form of reasoning deductively, translating, and transferring; 4) creating structure for input and output, in the form of taking notes, summarizing, and highlighting. While, component affective strategies used in writing are 1) lowering your anxiety, in the form of using progressive relaxation, deep breathing or mediation, using music, and using laughter; 2) encouraging yourself, in the form of making positive statement, taking risks wisely, and rewarding yourself; 3) taking your emotional temperature, in the form of listening to your body, using checklist, writing a language learning diary, and discussing your feeling with someone else.

Based on the result of SILL, component cognitive strategies used by the students are a) practicing in the form of repeating, formally practicing with patterns and writings, practicing naturalistically; b) analyzing and reasoning, in the form of translating; and c) creating structure for input and output in the form of taking notes and summarizing. On the other hand, component affective strategies used by the students are 1) lowering your anxiety, in the form of 
using progressive relaxation, deep breathing or mediation, using music, and using laughter; 2) encouraging yourself, in the form of taking risks wisely, and rewarding yourself; and 3) taking your emotional temperature, in the form of writing a language learning diary, and discussing your feeling with someone else.

\section{Memory Strategies}

Memory strategies help students in memorizing information well. Memory strategies help students in absorbing received information, saving it, and turning up when they answer the quiz or examination. Component of memory strategies used in writing are 1) creating mental linkages, in the form of placing new words in a context; 2) structured reviewing; and 3) employing action, in the form of using mechanical techniques. Then, results of SILL showed that component of memory strategies used by the students are 1) creating mental linkages in the form of placing new words into a context ;2) structured reviewing; and employing action in the form of using mechanical techniques.

\section{Social Strategies}

These strategies enable students to interact with social reality directly. When the students interact with others, they get two abilities directly; they get ability about language and ability to interact with others. Component of social strategies used in writing are 1) asking question, in the form asking for correction; 2) cooperating with others, in the form of cooperating with peers and cooperating with proficient users of the new language; and 3) empathizing with others in the form of developing cultural understanding and becoming aware of others' thoughts and feelings. Result of SILL showed that component social strategies used by the students are 1) asking for questions, in the form of asking for correction; 2) cooperating with others, in the form of cooperating with proficient users of the new language; and 3) empathizing with others, in the form of developing cultural understanding.

Learning strategies influence the students' writing score. From the whole subjects, it is gotten that the students' writing scores; good score and fair score. By using a 4-scale scoring system, these score represented by A and B mark. Good score is represented by A and fair score is represented by B score. Based on the result of SILL, learning strategies used by the students whose good score is metacognitive strategies, while learning strategies used by the students whose fair score is affective strategies. It means that learning strategies used by the students whose good score and fair score are different. Thus, it can be concluded that learning strategies influence students' score. 


\section{DISCUSSION}

Based on the research finding, the students use learning strategies in their learning. They use both direct and indirect strategies. There are six kinds of learning strategies used by the students; they are memory, cognitive, compensation, metacognitive, affective, and social strategies. Generally, metacognitive strategies are the most learning strategies used by the students in writing class. While, the most rarely learning strategies used by the students in writing class is affective class.

The result of SILL showed that the first strategies used by the students are metacognitive strategies. The students applied the strategies when they try to find out English language learning, organize aspects of English. Besides, the students also are able to determine goals and objectives of language learning plan for a language task. They can find out practice opportunities, evaluating their leaning by self-evaluating and self-monitoring

Then, second strategies used by the students in writing are compensation strategies. It used by the students in writing to solve language limitation by using coining words, using a circumlocution or synonym. They can also select the topic and adjust or approximate the message.

Cognitive strategies are the third strategies used by the students in their writing. Here, the students use the strategies when they practice to write naturalistically. They also try to use formulas and patterns well. Making summary and taking note are the application of cognitive strategies.

Next, learning strategies used by the students are affective students. It relates to students' emotion. When they write, they should be able to control their emotion when they have difficulties. The students should relax in writing or they can listen to music to make their brain fresh. They should be wise in facing the writing problems. To encourage themselves, they may reward themselves if they success write English well. Then, the students apply the strategies in writing learning diary or discussing their feeling to others.

The fifth strategies used by the students in writing are memory strategies. The strategies help the students to memorize English vocabulary. They use new vocabulary based on the context to make easier in remembering. They use mechanic technique to remember some new vocabularies.

Social strategies are the last strategies used by the students in writing. It used by the students when they have finished their writing, they ask others to correct their writing. It may the students to cooperate with proficient users of the new language to share idea or opinion. The students try to develop cultural understanding about English to improve their writing.

Besides, the result of SILL showed that the use of learning strategies by the students in their learning is moderate. It means that the students are rare or 
even never use learning strategies in their learning. Actually, learning strategies are important to determine the students' success in their learning. Learning strategies can facilitate the students in obtaining, storing, retrieving and using of information (Rigney \& Rubin as cited in Lee, 2010).

From the explanation above, it can be concluded that the students used learning strategies in their learning. For the details about leaning strategies used by the students, it is shown in Table 3.

Table 3. Strategies Used by the Students in Writing

\begin{tabular}{|c|c|c|c|}
\hline $\begin{array}{l}\text { Class of } \\
\text { strategy }\end{array}$ & Group of strategy & Set of strategy & Specific strategy \\
\hline \multirow[t]{2}{*}{ Indirect } & $\begin{array}{l}\text { Metacognitive } \\
\text { strategies }\end{array}$ & $\begin{array}{l}\text { Arranging and planning } \\
\text { your learning }\end{array}$ & $\begin{array}{l}\text { 1. finding out language } \\
\text { learning } \\
\text { 2. organizing } \\
\text { 3. setting goals and } \\
\text { objectives } \\
\text { 4. planning for a language } \\
\text { task } \\
\text { 5. Seeking practice } \\
\text { opportunities. }\end{array}$ \\
\hline & & Evaluating your leaning & $\begin{array}{l}\text { 1. self-evaluating } \\
\text { 2. self-monitoring }\end{array}$ \\
\hline Direct & $\begin{array}{l}\text { Compensation } \\
\text { strategies }\end{array}$ & Overcoming limitation & $\begin{array}{l}\text { 1. selecting the topic } \\
\text { 2. coining words } \\
\text { 3. using a circumlocution or } \\
\text { synonym }\end{array}$ \\
\hline \multirow[t]{3}{*}{ Direct } & $\begin{array}{l}\text { Cognitive } \\
\text { strategies }\end{array}$ & Practicing & $\begin{array}{l}\text { 1. repeating } \\
\text { 2. recognizing and using } \\
\text { formulas and patterns } \\
\text { 3. practicing naturalistically }\end{array}$ \\
\hline & & Analyzing and reasoning & Translating \\
\hline & & $\begin{array}{l}\text { Creating structure for } \\
\text { input and output }\end{array}$ & $\begin{array}{l}\text { 1.taking notes } \\
\text { 2.summarizing }\end{array}$ \\
\hline \multirow[t]{3}{*}{ Indirect } & $\begin{array}{l}\text { Affective } \\
\text { strategies }\end{array}$ & Lowering your anxiety & $\begin{array}{l}\text { 1. using progressive } \\
\text { relaxation, deep breathing } \\
\text { or meditation } \\
\text { 2. using music } \\
\text { 3. using laughter }\end{array}$ \\
\hline & & Encouraging yourself & 1. taking risks wisely \\
\hline & & $\begin{array}{l}\text { Taking your emotional } \\
\text { temperature }\end{array}$ & $\begin{array}{l}\text { 1. writing a language diary } \\
\text { 2. discussing your feeing } \\
\text { with someone else }\end{array}$ \\
\hline Direct & Memory & Creating mental linkages & 1.Placing new words into a \\
\hline
\end{tabular}

Journal on English as a Foreign Language, 8(1), 19-38

Copyright (C) 2018 by JEFL, p-ISSN 2088-1657; e-ISSN 2502-6615 


\begin{tabular}{|c|c|c|c|}
\hline \multirow{2}{*}{\multicolumn{2}{|c|}{ strategies }} & \multicolumn{2}{|r|}{ context } \\
\hline & & Reviewing well & Structured reviewing \\
\hline & & Employing action & Using mechanic technique \\
\hline \multirow[t]{2}{*}{ Indirect } & Social strategies & Asking questions & $\begin{array}{l}\text { 1. Asking for correction } \\
\text { 2. Cooperating with } \\
\text { proficient users of the new } \\
\text { language }\end{array}$ \\
\hline & & Empathizing with Others & $\begin{array}{l}\text { 1. Developing cultural } \\
\text { understanding }\end{array}$ \\
\hline
\end{tabular}

Source: Questionnaire and Document Analysis of SILL (Oxford, 2003)

Based on the documentations of students' writing score, it is classified into two groups, namely good and fair score. The students apply different learning strategies in their learning. From both classifications, there are different learning strategies used by the students in writing class. The students whose good score mostly used metacognitive strategies. On the other hand, the students whose fair score mostly used affective strategies. The difference of learning strategies used by the students in their learning with the students' writing score, it proved that learning strategies influence the students' score.

\section{CONCLUSION}

According to the result of research about learning strategies used by the students in writing, it can be concluded that the students of the second semester of Communication Science Department of the Muhammadiyah University of Ponorogo use learning strategies. Learning strategies used by the students in writing class are metacognitive, compensation, cognitive, affective, memory, and social strategies. Generally, the tendency of the students in using learning strategies is moderate. It means that the students sometimes use leaning strategies in their learning.

Learning strategies used by the students in their writing influence the students' writing score. The students whose good score use metacognitive strategies, while the students whose fair score use affective strategies. Therefore, learning strategies used by the students determine students' score. On the other side, the teacher should encourage the students in applying the learning strategies in order to the students are able to study maximally.

\section{REFERENCES}

Alfaki, D. I. (2015). University students' English writing problems: Diagnosis and remedy. International Journal of English Language Teaching , 40-52. 
Alfian. (2016). The application of language learning strategies of high school students in Indonesia. IJEE (Indonesian Journal of English Education), 141157.

Araúz, O. C. (2009). Language learning strategies and its implication on second language teaching. Revista de Lenguas Modernas, 399-411.

Arulselvi, E. (2006). Learning strategy training in English teaching. I-manager's Journal on English Language Teaching, 1-7.

Ching-Yi. (2007). A study of language learning strategies used by college EFL learners in Taiwan. Language Learning , 235-262.

Gestanti, R. A. (2017). Listening strategies employed by non-English department students. Journal on English as a Foriegn Language, 7(1), 35-58.

Hardan, A. (2013). Language learning strategies: A general overview. Procedia Social and Behavioral Sciences, 1712-1726.

Himasnoglu, M. (2000). Language learning strategies in foreign language learning and teaching. The Internet TESL Journal .

Lee, C. K. (2010). An overview of language learning strategies. ARECLS , 132152.

Liu, J. (2010). Language learning strategies and its training model. International Education Studies, 100-104.

Miftah, M. Z. (2015a). Enhancing writing ability through idea listing technique. Journal of English Education and Linguistics Studies (JEELS), 2(1), 62-83.

Miftah, M. Z. (2015b). Enhancing writing skill through writing process approach. Journal on English as a Foreign Language, 5(1), 9-24.

Mutiatun, N. (2017). Language learning strategies, motivation, and writing achievement of Indonesian EFL. Arab World English Journal (AWEJ), 250263.

Oxford, R. L. (2003). Language learning styles and strategies: An overview. GALA, 1-25.

Reszy, Y. H. (2013). Teaching writing a descriptive text by using environmental observation strategy. Journal of English Language Teaching , 28-38. 
Rini, S. (2016). Overview English as a second language for young learners. Register Journal, 9(1), 52-59.

Simsek, A. (2010). Contemporary educational technology. IJEE (Indonesian Journal of English Education), 36-45.

Tran-Hoang-Thu. (2009). Learning strategies used by successful language learners. Alliant International University.

Ungureanu, C. (2012). Learners' strategy in language learning. Procedia - Social and Behavioral Science, $5000-5004$.

Virdyna, N. K. (2016). Teaching writing skill by using brainwriting strategy. OKARA Journal of Languages and Literature , 67-77.

Zare, P. (2012). Language learning strategies among EFL/ESL learners: A review of 1Literature. International Journal of Humanities and Social Science, 162169.

\section{Author's Brief CV}

Dwiana Binti Yulianti is an English lecturer in Social and Political Science Faculty of the Muhammadiyah University of Ponorogo. Besides, she is also an instructor of Language Center. She gained her master degree in 2014 from Sebelas Maret University of Surakarta. She is currently teaching English for Specific Purposes (ESP) for Governmental Science. Teaching development for ESP class is her major study. 
